\section{Electric Power Supply in India}

$\mathrm{A}^{\mathrm{T}}$

T the annual meeting of the National Academy of Sciences, India, held on March 5, a symposium was arranged on the subject of India's power supply. In opening the discussion, Prof. M. N. Saha said that no subject could at the present moment be of greater importance than that of a cheap and abundant power supply. The whole industrial efficiency of a nation depends on it. He pointed out that there are countries in the world that have developed all their power resources-Norway, United States, England and Germany; but India, China and Abyssinia are still dependent on a medieval economy. In Norway, the total output per head per annum is nearly 1,800 units. In England and Germany the power is mainly derived from coal, but the output per head is probably nearly the same. In India the output cannot exceed 90 units, of which about 60 is from human labour, 10 from animal power and 20 from steam and electrical power combined.

If the problems of poverty and unemployment in India are to be solved, the power resources of the country must be organized so as to bring them to the level of Europe, America and Japan. Dr. Tandon said that the sponsors of the Ganges canal project would have done better service to the country if, instead of trying to capture the public imagination by the ideal of rural electrification, they had concentrated the load near the generating stations for the development of the heavy chemical industries.

Pandit J. Nehru, in summing up the discussion, said that everyone saw the necessity of establishing a power research and survey institute. But democratic Governments are greatly burdened by their ordinary routine work, and complaints from innumerable persons who now have access to them. The first things they do are naturally those demanded by hundreds of thousands of people, and so they have no time to listen to the counsels of a few dozen, however great their reputation may be. The expert man of science is not always a helpful person. $\mathrm{He}$ does not realize that things which have to be put before the Government must be definite and that the proposals must fit in with the realities of the situation. He asked the Academy to draw up definite proposals for benefiting the nation, and not vague aspirations as to what should or might be done.

At a subsequent meeting on March 29, Prof. Saha moved a series of resolutions which were unanimously carried. The Government is requested to appoint a committee of legal and scientific experts, and representatives of industry, to study the present Electricity Act and to recommend the necessary legislation required to nationalize the generation and distribution of electricity with the view of making the supply of electrical power in the country cheap and abundant. The second resolution requests the Government to select a body of graduates in physics and electrical and chemical engineering, and to send them to study the methods adopted in countries such as England, the U.S.S.R. and Switzerland. The third resolution is a request that a permanent body called the "Power Survey and Research Institute" be appointed. Finally, the National Academy noted with regret that the Government of the United Provinces, when appointing an Electricity Committee, did not consider it necessary to ask the Academy to nominate a specialist to serve on the Committee.

\section{Science News a Century Ago}

\section{Invention of Daguerrotype}

ON January 7, 1839, Arago described to the Paris Academy of Sciences the invention of Louis Jacques Mande Daguerre (1789-1851) for the photographic process of taking pictures on metal plates. Writing from Paris, a correspondent of the Athenceum said, "So universal an interest was excited here by the paper read by M. Arago, that I called on M. Daguerre to possess myself, as far as was permissible, of the facts of this very extraordinary discovery. . . . Of course, I can as yet give no precise details as $\mathbf{M}$. Daguerre naturally objects to impart them to anyone, till he has received definite answer from the Government, with whom he is in treaty for the sale of his secret. I should add that the discovery is authenticated past the power of question by the testimonials of such men as Biot, von Humboldt and M. Arago. His earlier sketches of four years ago have a slight haziness ; some of his last works have the force of Rembrandt's etchings." Of the various subjects of Daguerre pictures, the correspondent mentioned the Quays of Paris, the Louvre and Notre Dame, the picture of the last having been taken in the rain.

Daguerre had begun life as an inland revenue officer, then became a stage painter, and in 1822, in conjunction with M. Bouton, opened the Diorama in Paris, which for seventeen years was a great attraction. For many years he endeavoured to produce permanent pictures by the action of sunlight, and collaborated with Nicéphore Niepce (1765-1833). Daguerre's pictures were produced on plates of silver covered with a film of iodide. After exposure, the plates were developed by means of mercury vapour and fixed in a bath of hyposulphite of soda.

\section{Parallax of $\alpha$ Centauri}

ON January 9, 1839 , the discovery of the parallax of $\alpha$ Centauri was communicated to the Royal Astronomical Society by Thomas Henderson (17981844), the first Astronomer Royal for Scotland, to which office he had been appointed in 1834, a year after his return from the Cape of Good Hope. "With a view," said Miss Clerke, "to correcting the declination of the lustrous double star $\alpha$ Centauri . . . he effected a number of successive determinations of its position, and on being informed of its very considerable proper motion $\left(3 \cdot 6^{\prime \prime}\right)$ annually he resolved to examine the observations already made for possible traces of parallactic displacement. This was done on his return to Scotland. . . From the declination measurements made at the Cape and duly reduced, a parallax of about one second of are clearly emerged . . . but, by perhaps an excess of caution, was withheld from publication until fuller certainty was afforded by the concurrent testimony of Lieutenant Meadows' determinations of the same star's right ascension. When at last, January 9, 1839, Henderson communicated his discovery to the Astronomical Society, he could no longer claim the priority which was his due. Bessel had anticipated him with the parallax of 61 Cygni by just two months."

\section{William MacMichael (1784-r839)}

Dr. William MacMichagl, an eminent London physician, who died on January 10, 1839, was born at Bridgnorth in Shropshire in 1784, the son of a 
banker. He was educated at the local grammar school and Christ Church, Oxford, where he qualified in 1808. Appointed Radcliffe travelling fellow in 1811, he visited Russia, Turkey, the Balkan States and Palestine, and in 1817 and 1818 recorded his experiences of the journey. In 1818 he settled in London and four years later was appointed physician to the Middlesex Hospital. In 1829 he was made physician extraordinary to the King. At the Royal College of Physicians, of which he was elected fellow in 1818, he held the office of censor in 1822 and 1832 and of registrar in 1824. MacMichael is best known as the author of "The Gold Headed Cane" which was published anonymously in 1827 and contained the lives of Radcliffe, Mead, Askew, Pitcairn and Baillie, the successive owners of the cane, now in possession of the Royal College of Physicians. He was also the author of "Lives of British Physicians" (1830), also published anonymously and written in the same delightful style as the previous work, as well as of unimportant books on scarlet fever (1822) and cholera (1831).

\section{Magnetical Observations}

IN its report of the meeting of the Royal Society held on January 10, 1839, the Athenceum included the report to the Council by the Joint Committee of Physics and Meteorology appointed to consider the propriety of recommending the establishment of fixed magnetic observatories and the equipment of a naval expedition for observations in the Antarctic. The report, signed by Sir John Herschel, was approved, and Herschel, together with Sabine and Wheatstone, were requested to wait on Lord Melbourne. After reading the report, Lord Melbourne stated that he would urge Her Majesty's Government to adopt measures for carrying the resolution of the Council into immediate effect.

\section{University Events}

CAmbridge.-The International Wool Publicity and Research Secretariat is supporting in the University a research studentship at the School of Biochemistry, and on the conclusion of the present holder's tenure it will consider providing for a further tenure appointment to which will be made by the University. The present holder is $R$. L. M. Synge, of Trinity College.

L. C. Young, of Trinity College, has been approved for the degree of Sc.D.

Dr. W. Feldberg has been appointed University lecturer in physiology.

The subject proposed for the Adams Prize for the period 1939-40 is "The Theory of Numbers". This phrase may be interpreted in the widest sense and as including, for example, the additive, algebraic, analytic and geometric theories.

Reading.-Prof. F. J. Cole, professor of zoology since 1906, is resigning from the chair in September. Prof. Cole's researches have dealt chiefly with comparative anatomy and the history of zoology. From 1895 until 1906 he was lecturer in zoology in the University of Liverpool.

\section{Societies and Academies}

\section{London}

Royal Society (Proc., A, 169, 1-148; 1938).

Sir William Bragg: Presidential address.

J. L. Lizrus and A. J. Allmand: The simultaneous sorption of carbon bisulphide and water vapour by activated charcoals.

R. F. BARrow and W. Jevons: The band spectrum of silicon monosulphide and its relation to the band spectra of similar molecules.

R. W. Sillars : The behaviour of polar molecules in solid paraffin wax.

J. SAYERS: Ionic recombination in air.

P. Weiss : (I) On the Hamilton-Jacobi theory and quantization of a dynamical continuum. (2) On the Hamilton-Jacobi theory and quantization of generalized electrodynamics.

E. A. GUGGENHEIM : The statistical mechanies of co-operative assemblies.

\section{Edinburgh}

Royal Society of Edinburgh, December 5.

A. R. GLen : The Oxford University Arctic Expedition to North East Land, 1935-1936. The north coast of the island was mapped in detail, while reconnaissance surveys were made of the east and south coasts. The ionosphere research carried on at the base in Brandy Bay yielded results of considerable value to the further development of world wireless communications, while measurements of the atmospheric ozone and observations on the aurora were successfully made. The geology and biology of North East Land were studied in some detail. Finally, at two stations established on the inland ice a comprehensive programme of glaciological and meteorological research was completed.

Vera Fretrer : Structure and function of the alimentary canal of some tectibranch molluses. with a note on excretion. The morphology, minute structure and functioning of the gut of four species of tectibranch molluses has been described. Food, sensed by cephalic sense organs and raked in by the radula, is crushed by calcareous plates in the gizzard and exposed to enzymes from the salivary and digestive glands. Digestion of carbohydrates, proteins and fats occurs, soluble products and minute particles being passed through the stomach to the liver for absorption and further digestion. Indigestible food from the digestive gland is excreted via the anus and the kidney in different proportions in bivalves and gastropods.

Mrs. E. M. Beattie : Investigation of visual threshold values. The main object of the work was the determination of the effect of fatigue, under certain conditions, on the magnitude of the threshold value. The time of fatigue by a light of given intensity was varied, and it was found that the apparent intensity, as measured by the critical frequency of flicker, of onother light, also of constant intensity, was markedly increased by increase of the time of fatigue. The same condition holds when an interval of time elapses between the cessation of fatigue and observation of the second light, but the effect is smaller. 